\title{
CRYOPROTECTIVE EFFICACY OF LOCAL FRIESIAN BULL'S SPERMATOZOA USING TRIS-EXTENDER ENRICHED WITH NATURAL OR SYNTHETIC ANTIOXIDANTS
}

\section{Y. S. Hussein}

Biotechnology Research Department, Animal Production Research Institution, Dokki, P. O. Box 443, 23221, Giza, Egypt, E-mail: yshussein@hotmail.com

Received: 5/9/2017

SUMMARY

There are many research articles on using antioxidants, regardless of its source of synthesis, in semen cryopreservation against the hazards of free radicals. Two types of natural antioxidants and synthetic one were added to Tris based extender in the current research. Semen samples were collected biweekly from thirty five local Friesian bulls, pooled, then divided into seven groups (Basic) and three supplementations with two levels of each; Ubiquinone-10 (0.02mM and 0.03mM), L-Carnitine (2mM and $3 \mathrm{mM})$ and N-Acetyl-L-Cysteine (1.0mM and $1.5 \mathrm{mM})$. All groups were packed and cryopreserved in $0.5 \mathrm{ml}$ French straw under $L N_{2}$. Sperm assessment parameters were estimated after dilution and after thawing. Recovery rates and enzymatic activities of AST, $A L T$ and $L D H$ were evaluated after thawing. Generally, addition of antioxidants significantly enhanced all sperm assessment parameters and recovery rates with delayed activity of seminal enzymes than control group. However; the best semen characteristics $(P<0.05)$ were found in both $U B-10(0.03 \mathrm{mM})$ and NAC $(1.0 \mathrm{nM})$ additions with an advantage to UB-10 $(0.03 \mathrm{mM})$ in motility and livability of spermatozoa. Also, treatment of diluted semen with $L C$ enhanced post-thawing recovery rates $(P<0.05)$ of all semen assessment parameters than $B E$ group only. Current results revealed the promising improvements of UB-10 as a natural antioxidant and $N A C$ as a synthetic one that able to enhance mobility, viability and maintains acrosomal integrity of cryopreserved local Friesian bull's spermatozoa.

Keywords: Friesian bulls, semen extender, antioxidants, L-Carnitine, Ubiquinone-10, N-Acetyl-L-Cysteine.

\section{INTRODUCTION}

During semen cryopreservation, the spermatozoa are subjected to chemical, toxic, osmotic, thermal, mechanical and oxidative stresses during dilution, cooling, equilibration, or freezing and thawing stages that delays its motility and viability. Hence, sperm plasma membrane has abundant polyunsaturated fatty acid; makes them potentially susceptible to reactive oxygen species (ROS); induces lipid peroxidation (LPO) to sperm membranes, damage to proteins, DNA fragmentation and enzyme inactivation; leading to a decrease of post-thawing sperm motility and viability of bull semen (Dos Santos et al., 2009 and Gualtieri et al., 2014).

Regardless of its original source, antioxidants are used as a scavenging tool against the hazards of free radicals in semen cryopreservation. Further research investigated whether enzymatic or not; but none of which discussed its synthesis origin; if it is natural or synthetic. The aim of the current research is to study Ubiquinone-10 and L-Carnitine as natural antioxidants from different sources versus N-AcetylL-Cysteine synthetic non-phenolic one; in Tris based extender. The Ubiquinone-10, known as Co-Enzyme Q10, is a cellular antioxidant produced especially from mitochondria and found in the middle-piece of spermatozoa as well (Tariq et al., 2015). In the meantime, L-Carnitine is found with high concentration in epididymis and secreted in seminal plasma (Matalliotakis et al., 2000). On the other hand, N-Acetyl-L-Cysteine that known as NAcetylcysteine was initially patented in 1960 and licensed for use in 1968 (Fischer and Ganellin, 2006) and has many medicinal benefits.

\section{MATERIALS AND METHODS}

Both Ubiquinone-10 (UB-10), c9538 and NAcetyl-L-Cysteine (AC), A7250 were obtained from Sigma Aldrish Co. St. Louis, MO, USA. Meanwhile L-Carnitine (LC) was purchased from Roche Diagnostics GmbH, Mannheim, Germany.

\section{Animals and semen collection:}

A total of 35 sexually mature local Friesian bulls $(350-400 \pm 50 \mathrm{~kg})$ were maintained at El-Gemmezah Animal Production Research Station, Animal Production Research Institute, Agricultural Research Center, Egypt. Ejaculates more than $70 \%$ mass motility were collected biweekly, for five successive weeks, using an artificial vagina; then taken immediately to the laboratory for semen evaluation and processing.

\section{Preparation of cryopreservation medium:}

The experimental basic extender of bull semen was Tris-citric acid-egg yolk extender. The extender was divided into seven groups; control (BE, Basic Extender) and three treatments with two levels of each; Ubiquinone-10 (UB-10, $0.02 \mathrm{mM}$ and UB-10, 
$0.03 \mathrm{mM}$ ), L-Carnitine (LC, $2 \mathrm{mM}$ and LC, $3 \mathrm{mM}$ ) and N-Acetyl-L-Cysteine (NAC, $1.0 \mathrm{mM}$ and NAC, $1.5 \mathrm{mM})$, per $100 \mathrm{ml}$., extender. Semen processing, cryopreservation and thawing
processes:

The collected semen was pooled and divided equally according to above mentioned seven groups with evaluated dilution rate 1:10 then packed into 0.5 $\mathrm{ml}$ medium- sized French straws and cryopreserved into liquid nitrogen $\left(\mathrm{LN}_{2}\right)$ at $-196^{\circ} \mathrm{C}$ after $4 \mathrm{~h}$ equilibration time at $5^{\circ} \mathrm{C}$. One month later; frozen straws were thawed at $37^{\circ} \mathrm{C}$ for $30 \mathrm{~s}$ in water bath to be evaluated.

\section{Semen evaluation and enzymatic activity:}

Semen extended with each treatment level was evaluated in post- dilution and post-thawed semen samples according to Salisbury et al. (1978). Percentage of progressive motility was held using stage microscope at X20 objective lens. Meanwhile; viability and morphological abnormalities, of at least 200 spermatozoa, were done using Eosin (0.5\%)Nigrosin $(0.1 \%)$ staining mixture; dead cells were stained by the Eosin (Barbas, and Mascarenhas, 2009). In the meantime, the counting of acrosomal membrane intact was done by immerging of air dried $30 \mu \mathrm{l}$ of thawed semen into previously prepared Giemsa's stain solution and kept at $37^{\circ} \mathrm{C}$ for $2 \mathrm{hrs}$ (Chowdhury et al., 2014). Membrane permeability (Hypoosmotic Swelling Test, HOST) in $100 \mathrm{mOsm} / \mathrm{L}$ was held to evaluate the functional intact sperm plasma membrane, based on swollen tails (HufanaDuran et al., 2015). The hypo-osmotic solution consisted of $7.35 \mathrm{~g}$ sodium citrate and $13.51 \mathrm{~g}$ fructose dissolved in one liter of distilled water. Concisely, $500 \mu \mathrm{l}$ of hypo-osmotic solution was mixed with $50 \mu \mathrm{l}$ of frozen-thawed semen and was incubated at $37^{\circ} \mathrm{C}$ for one hour. Thereafter, a drop of well mixed semen was placed on a glass slide and covered with a cover slip. At least 200 spermatozoa were counted in different fields under $400 \mathrm{x}$ phase contrast microscope. The recovery rate after thawing was estimated for each parameter according to Zhang el al. (2012) except for sperm abnormalities as follows:

$$
\text { Parameter' recovery rate } \%=\frac{\% \text { Sperm parameter after thawing }}{\% \text { Sperm paraneter post dilution }} \times 100
$$

Table 1. Post dilution impact of different levels of antioxidants enriched extender on sperm assessment parameters (Mean \pm SE) on local Friesian bull's semen

\begin{tabular}{|c|c|c|c|c|c|}
\hline \multirow[b]{2}{*}{$\begin{array}{c}\text { Extender } \\
\text { Enrichment }\end{array}$} & \multicolumn{5}{|c|}{ Sperm parameters (\%) } \\
\hline & Motility & livability & Abnormality & $\begin{array}{c}\text { Hypoosmotic Swelling } \\
\text { Test }\end{array}$ & $\begin{array}{l}\text { Acrosomal } \\
\text { Intact }\end{array}$ \\
\hline Basic Extender & $68.40^{\mathrm{a}} \pm 1.03$ & $66.00^{\mathrm{a}} \pm 1.45$ & $28.40^{\mathrm{e}} \pm 1.72$ & $69.60^{\mathrm{a}} \pm 1.40$ & $74.40^{\mathrm{a}} \pm 0.93$ \\
\hline UB-10 (0.02mM) & $75.00^{\mathrm{bc}} \pm 1.58$ & $72.40^{c} \pm 0.68$ & $18.60^{\mathrm{b}} \pm 1.21$ & $73.80^{\mathrm{abc}} \pm 1.20$ & $80.00^{\mathrm{c}} \pm 0.84$ \\
\hline UB-10 (0.03mM) & $77.40^{c} \pm 1.12$ & $78.40^{\mathrm{d}} \pm 1.75$ & $13.60^{\mathrm{a}} \pm 0.68$ & $77.00^{\mathrm{c}} \pm 1.22$ & $83.60^{\mathrm{d}} \pm 0.51$ \\
\hline LC $(2 \mathrm{mM})$ & $70.00^{\mathrm{ab}} \pm 1.58$ & $68.60^{\mathrm{ab}} \pm 0.81$ & $24.40^{\mathrm{d}} \pm 1.17$ & $71.20^{\mathrm{a}} \pm 0.97$ & $73.40^{\mathrm{a}} \pm 0.51$ \\
\hline LC (3mM) & $72.00^{\mathrm{ab}} \pm 2.00$ & $68.80^{\mathrm{abc}} \pm 1.02$ & $22.60^{\mathrm{cd}} \pm 1.60$ & $72.40^{\mathrm{ab}} \pm 1.25$ & $74.20^{\mathrm{a}} \pm 0.37$ \\
\hline NAC $(1.0 \mathrm{mM})$ & $75.00^{\mathrm{bc}} \pm 1.58$ & $76.80^{\mathrm{d}} \pm 1.32$ & $17.20^{\mathrm{b}} \pm 0.86$ & $76.20^{\mathrm{bc}} \pm 1.85$ & $81.60^{c} \pm 0.51$ \\
\hline NAC $(1.5 \mathrm{mM})$ & $74.00^{\mathrm{bc}} \pm 1.87$ & $71.80^{\mathrm{bc}} \pm 1.07$ & $19.20^{\mathrm{bc}} \pm 0.86$ & $73.80^{\mathrm{abc}} \pm 1.88$ & $77.40^{\mathrm{b}} \pm 0.51$ \\
\hline
\end{tabular}

Seminal aspartate- (AST) and alanine- (ALT) aminotransferases enzymatic activities were estimated (Schmidt and Schmidt, 1963) and lactate dehydrogenase (LDH) was also determined as well (Howell et al., 1979).

\section{Statistical analysis:}

Data were statistically analyzed by the least square analysis of variances ANOVA using SAS (2009) software. Duncan multiple range test was used to test the differences among means (Duncan, 1955).

\section{RESULTS}

Generally, after dilution, BE enriched with antioxidants significantly enhanced progressive motility $(P<0.001)$, livability $(P<0.0001)$, sperm membrane permeability $(P<0.05)$ and intact of sperm acrosome $(P<0.0001)$; while sperm abnormalities was minimum $(P<0.0001)$ as presented in Table $(1)$. Meanwhile, after thawing, (Table 2); all sperm assessment parameters were significantly enhanced $(P<0.0001)$ as a result of antioxidants supplementation. However; the best semen characteristics were found in both UB-10 $(0.03 \mathrm{mM})$ and NAC $(1.0 \mathrm{nM})$ additions with advantage $(P<0.05)$ to UB-10 $(0.03 \mathrm{mM})$ in motility and livability of spermatozoa. Same results were obtained for enzymatic activity as shown in Table (3). The $0.03 \mathrm{mM}$ concentration of UB-10 shares the significant best sperm recovery rate for motility with NAC; $1.0 \mathrm{mM}(85.28 \%$ and $79.5 \%$ respectively) and livability with LC; $3 \mathrm{mM}(87.55 \%$ and $87.27 \%$, respectively) as presented in Figs. (1 and 2). Furthermore, both UB-10 concentrations displayed the better sperm membrane permeability $(88.45 \%$ acrosomal intact recovery rate was for LC levels (95.30\% and 94.38\%, respectively; Fig. 4), although insignificant difference among all extender treatments were observed.

Ubiquinone-10 known as a bioenergetic compound responsible for electrons and protons transport in the process of energy production, leading to ATP synthesis within mitochondrial membrane needed for maintaining and enhancing sperm motility (Lenaz and Genova, 2009). and $87.09 \%$ respectively; Fig. 3). In addition, the best

$\mathrm{a}, \mathrm{b}, \mathrm{c}, \mathrm{d}$ and e: Means within each column followed by different letters differ at $P<0.05$. 
Egyptian J. Anim. Prod. (2018)

Table 2. Post-thawing sperm assessment parameters (Mean \pm SE) of local Friesian bull's semen extender as affected by different levels of antioxidants

\begin{tabular}{|c|c|c|c|c|c|}
\hline \multirow{2}{*}{$\begin{array}{c}\text { Extender } \\
\text { Enrichment }\end{array}$} & \multicolumn{5}{|c|}{ Sperm parameters (\%) } \\
\hline & Motility & livability & Abnormality & $\begin{array}{l}\text { Hypoosmotic } \\
\text { Swelling Test }\end{array}$ & $\begin{array}{c}\text { Acrosomal } \\
\text { Intact }\end{array}$ \\
\hline Basic Extender & $48.40^{\mathrm{a}} \pm 0.75$ & $54.40^{\mathrm{a}} \pm 1.63$ & $47.00^{\mathrm{e}} \pm 2.10$ & $57.00^{\mathrm{a}} \pm 1.26$ & $53.60^{\mathrm{a}} \pm 2.89$ \\
\hline UB-10 $(0.02 \mathrm{mM})$ & $54.80^{\mathrm{bcd}} \pm 2.42$ & $62.60^{\mathrm{cd}} \pm 1.33$ & $28.00^{\mathrm{b}} \pm 0.71$ & $64.20^{\mathrm{c}} \pm 1.20$ & $71.40^{\mathrm{cd}} \pm 0.75$ \\
\hline UB-10 (0.03mM) & $66.00^{\mathrm{e}} \pm 1.30$ & $68.60^{\mathrm{e}} \pm 1.17$ & $23.00^{\mathrm{a}} \pm 0.71$ & $68.00^{\mathrm{d}} \pm 0.84$ & $76.60^{\mathrm{e}} \pm 1.40$ \\
\hline $\mathbf{L C}(2 \mathrm{mM})$ & $50.00^{\mathrm{ab}} \pm 2.24$ & $56.80^{\mathrm{ab}} \pm 0.80$ & $33.60^{\mathrm{d}} \pm 1.03$ & $58.60^{\mathrm{ab}} \pm 0.87$ & $67.00^{\mathrm{b}} \pm 0.84$ \\
\hline $\mathbf{L C}(3 \mathrm{mM})$ & $52.00^{\mathrm{abc}} \pm 1.22$ & $60.00^{b c} \pm 0.32$ & $31.40^{\mathrm{cd}} \pm 1.03$ & $59.60^{\mathrm{ab}} \pm 0.24$ & $68.20^{b c} \pm 1.16$ \\
\hline NAC $(1.0 \mathrm{mM})$ & $59.60^{\mathrm{d}} \pm 1.03$ & $64.00^{\mathrm{d}} \pm 1.61$ & $26.00^{\mathrm{ab}} \pm 0.32$ & $66.00^{\mathrm{cd}} \pm 1.14$ & $73.40^{\mathrm{de}} \pm 0.40$ \\
\hline NAC $(1.5 \mathrm{mM})$ & $57.00^{\mathrm{cd}} \pm 2.00$ & $61.20^{\mathrm{cd}} \pm 0.58$ & $29.20^{\mathrm{bc}} \pm 0.37$ & $60.80^{\mathrm{b}} \pm 0.66$ & $68.80^{\mathrm{bc}} \pm 0.66$ \\
\hline
\end{tabular}

$\mathrm{a}, \mathrm{b}, \mathrm{c}, \mathrm{d}$ and e: Means within each column followed by different letters differ at $P<0.05$.

Table 3. Enzymatic activity (Mean \pm SE) of post-thawed local Friesian bull's seminal plasma supplemented with different levels of antioxidants

\begin{tabular}{llll}
\multicolumn{1}{c}{$\begin{array}{c}\text { Extender } \\
\text { Enrichment }\end{array}$} & \multicolumn{1}{c}{ AST } & \multicolumn{2}{c}{ Enzyme concentration (IU/I) } \\
ALT & \multicolumn{1}{c}{ LDH } \\
\hline Basic Extender & $40.20^{\mathrm{c}} \pm 1.56$ & $28.80^{\mathrm{d}} \pm 1.07$ & $315.40^{\mathrm{e}} \pm 9.81$ \\
UB-10 $(0.02 \mathrm{mM})$ & $23.80^{\mathrm{a}} \pm 0.66$ & $21.00 \mathrm{~b}^{\mathrm{c}} \pm 1.30$ & $247.20^{\mathrm{bc}} \pm 7.55$ \\
UB-10 $(0.03 \mathrm{mM})$ & $21.40^{\mathrm{a}} \pm 1.12$ & $17.20^{\mathrm{a}} \pm 1.02$ & $215.00^{\mathrm{a}} \pm 6.71$ \\
LC $(2 \mathrm{mM})$ & $29.20^{\mathrm{b}} \pm 0.66$ & $23.20^{\mathrm{c}} \pm 1.50$ & $274.00^{\mathrm{d}} \pm 4.79$ \\
LC $(3 \mathrm{mM})$ & $30.00^{\mathrm{b}} \pm 1.38$ & $23.60^{\mathrm{c}} \pm 1.03$ & $281.40^{\mathrm{d}} \pm 5.98$ \\
NAC $(1.0 \mathrm{mM})$ & $22.20^{\mathrm{a}} \pm 1.11$ & $19.00^{\mathrm{ab}} \pm 0.71$ & $240.80^{\mathrm{b}} \pm 4.77$ \\
NAC $(1.5 \mathrm{mM})$ & $24.40^{\mathrm{a}} \pm 0.93$ & $22.00^{\mathrm{bc}} \pm 0.84$ & $265.40^{\mathrm{cd}} \pm 5.25$ \\
\hline
\end{tabular}

$\mathrm{a}, \mathrm{b}, \mathrm{c}, \mathrm{d}$ and e: Means within each column followed by different letters differ at $P<0.05$.

UB-10= Ubiquinone-10), LC $=\mathrm{L}-$ Carnitine, NAC=N-Acetyl-L-Cysteine, AST=Aspartate Aminotransferase ALT $=$ Alanine Aminotransferase and $\mathrm{LDH}=$ Lactate dehydrogenase.

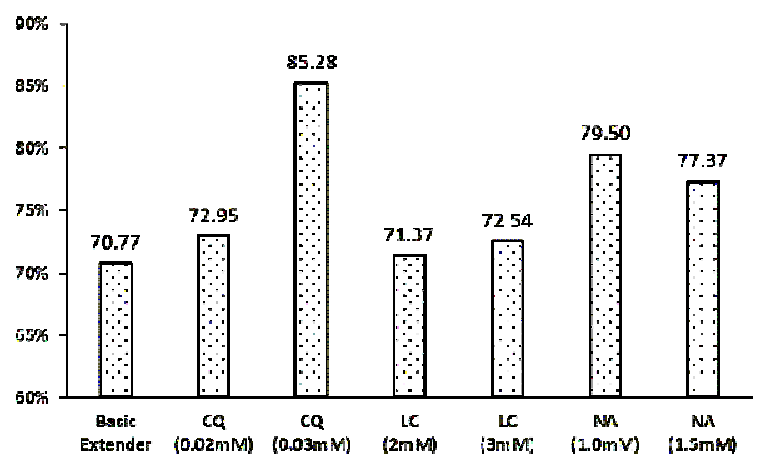

Fig. 1. Effect of Tris extender treated with different antioxidants sperm progressive motility recoverv rates.

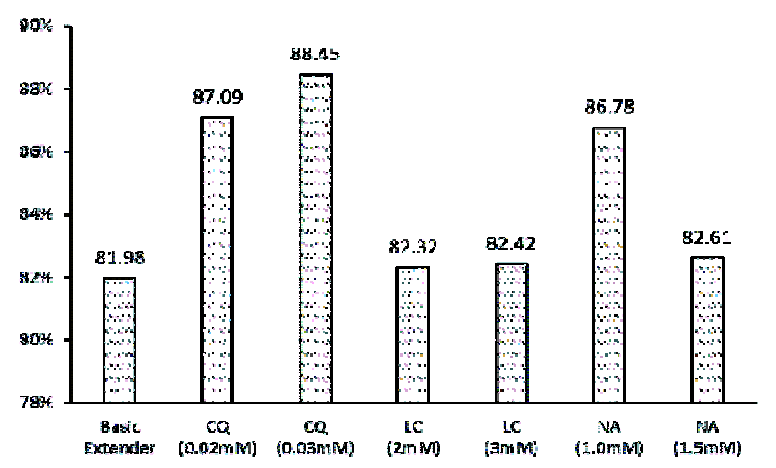

Fig. 3. Hypoosmotic Swelling Test in response to different antioxidant supplementation to tris extender

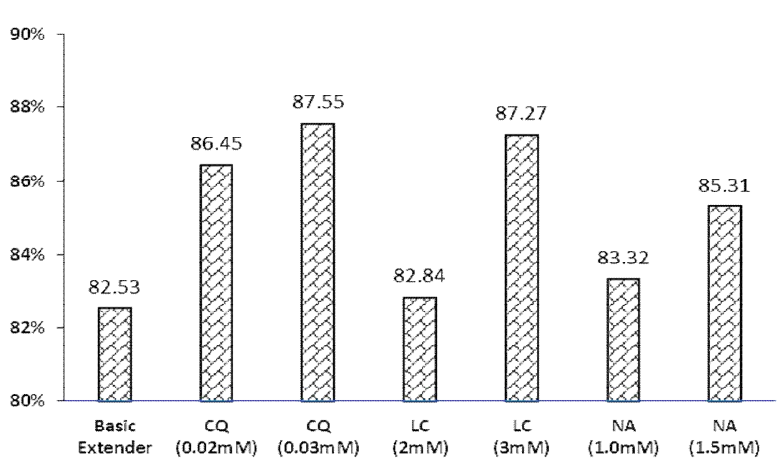

Fig. 2. Recovery rates of sperm livability as affected by different antioxidants added to tris extender

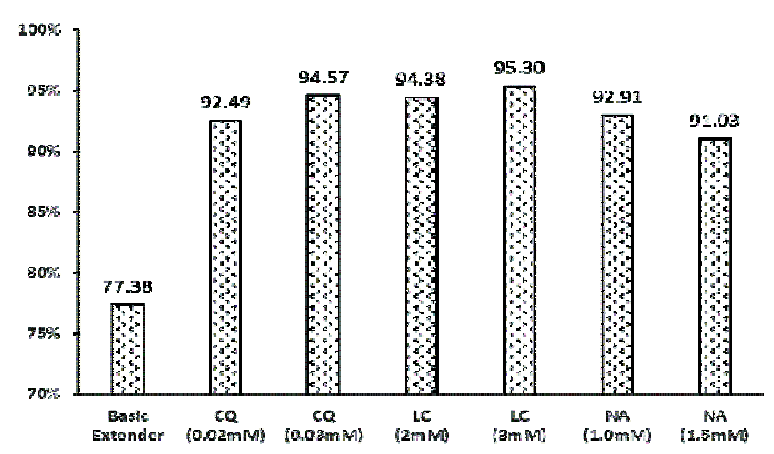

Fig. 4. Recovery rates of sperm acrosomal Intact as affected by different antioxidants added to tris extender 


\section{DISCUSSION}

Current experimental results support the fact that naturally or synthetic phenolic butylated hydroxytoluene antioxidants systems are the defense functioning mechanisms against LPO of oxidative stressed spermatozoa (Shoae and Zamiri, 2008), and thus improve the quality of cryopreserved semen (Tariq et al., 2015).

The continuous production of ROS leads to imbalance with endogenous antioxidants from sperm cells and seminal plasma which are in low concentrations, whether enzymatic or not (O'Flaherty, 2014). These events increased the number of abnormal and immature sperm cells that adversely affecting sperm motility, viability and fertilizing potential (Sikka, 2004).

Based on previous facts, current study results point to that cellular originated antioxidants like UB10 has the most powerful influence on the quality of Egyptian bull's sperm after freezing-thawing process when compared to all experimental groups. It might act at both intra- and inter-cellular levels.

On the other hand, UB-10 supports and stabilizes the mitochondrial oxidative phosphorylation against free radicals (Miles, 2007) that provides the protective benefits for bull spermatozoa against damage (Gualtieri et al., 2014). That was clearly observed with $0.03 \mathrm{mM}$ concentration of UB-10 (Fatimah et al., 2011). Current findings are in agreement with those reported by Saeed et al. (2016) who found that UB-10 $(30 \mu \mathrm{M})$ enhanced both buffalo and cattle sperm motility, livability, membrane integrity with a great reduction in sperm abnormalities and damaged acrosome.

Similar enhancements on semen assessment parameters were observed for the synthetic antioxidant focused in the concentration of $1.0 \mathrm{mM}$ of NAC. It seems that NAC probably works at the intracellular level; since there is evidence that the neutral form of NAC has that ability to penetrate cell membrane by passive diffusion because of its low molecular weight (Samuni et al., 2013).

N-Acetyl-L-Cysteine known as scavenger of ROS, as a precursor of L-cysteine, the precursor of the biologic antioxidant glutathione (Rushworth and Megson, 2014) in human (Ciftci et al., 2009) and canine (Michael et al., 2007) semen. Hence, the higher progressive motility, plasma membrane, acrosomal integrities are correlated to L-cysteine levels (Patel et al., 2016). However, some studies found that NAC did not improve Post-thawing motility in bull (Pinto et al., 2017) or ram (Ari et al., 2016) spermatozoa. Additionally, NAC found to exert attenuated action on both TGF- $\beta 1$ antiproliferative and glutathione-depleting effects that delay cellular proliferation of endothelial cells (Das et al., 1992) and enhance the secretion of both IL-10 and IL-12 of human alveolar macrophage $(\mathrm{Cu}$ et al. 2009); assuming that NAC is not only acting as an antioxidant but also as preventive compound against cell apoptosis (Dhouib et al., 2016). Further researches could be a clue for the supported effect/s of NAC on bull spermatozoa.

On the other hand, addition of LC to semen extender improves sperm motility and viability not only for post-thawing recovery rates but also for diluted semen just than BE group. Current results are supported by several studies on the ameliorative impact of LC on the quality of bull spermatozoa (Sato et al., 2008 and Abdel-Khalek et al., 2015).

Finally, in relation to antioxidant defenses, current results showed a significant $(P<0.0001)$ lower leakage of enzymatic activity of diluted seminal plasma after thawing which were in agreement with Patel et al., (2016). Low incidence of acrosomal changes of current results is evidenced by the lower AST, ALT and LDH activities due to antioxidant enrichment to semen extender than $\mathrm{BE}$ group. Good semen quality is characterized by lower AST, ALT and LDH activities (Taha et al., 2000 and El-Harairy et al., 2011), that could be due to lower injuries occurred to sperm membrane (Borah et al. 2015) as evidenced by significantly low acrosomal changes occurred in the current study.

\section{CONCLUSION}

There is a broad range of antioxidants but which is suitable and with what concentration? Present study revealed promising results for UB-10 $(0.03 \mathrm{mM})$ as a natural antioxidant and NAC $(1.0 \mathrm{mM})$ as a synthetic one which are able to enhance sperm progressive mobility and viability with a strong protective power against acrosomal damage of local born Friesian bull's spermatozoa. However, more research is needed to investigate the addition efficiency of both UB-10 and NAC and their mixture in semen extender and at which supplementation limit.

\section{REFERENCES}

Abdel-Khalek E., H.K. Zaghlool and Sh. A. Gabr, 2015. Performance and semen traits of Friesian bulls administrated with free L-Carnitine as metabolic regulator. Asian Journal of Animal Sciences, 9: 13-24.

Ari U. C., R. Kulaksiz, Y. Öztürkler, N. C. Lehimcioğlu and S. Yildiz, 2016. Effect of NAcetylcysteine (NAC) on post-thaw semen quality of tushin rams. Kafkas Univ Vet Fak Derg 22 (6): 883-887.

Barbas, J.P. and R.D. Mascarenhas, 2009. Cryopreservation of Domestic Animal Sperm Cells. Cell and Tissue Banking, 10, 49-62.

Borah B.K.D., B. C. Deka, R. K. Biswas, P. Chakravarty, S. Deori, S. Sinha and K. Ahmed, 2015. Effect of thawing methods on frozen semen quality of yak (Poephagusgrunniens L.) bulls. Vet World, 8(7): 831-834. 
Chowdhury S., S. Das, T. Gupta, D. Sana and S. Bose, 2014. Evaluation of frozen semen by acrosomal integrity and sperm concentration two vital quality parameters of male fertility in bovines Explor Anim Med Res, 4(1), p 101-107

Ciftci H., A. Verit, M. Savas, E. Yeni, and O. Erel, 2009. Effects of N-acetylcysteine on Semen Parameters and Oxidative/Antioxidant Status. Urology 74: 73-76.

$\mathrm{Cu}$ A., Q. Ye, R. Sarria, S. Nakamura, J. Guzman, U. Costabel, 2009. N-acetylcysteine inhibits TNFalpha, sTNFR, and TGF-beta1 release by alveolar macrophages in idiopathic pulmonary fibrosis in vitro. Sarcoidosis Vasc Diffuse Lung Dis; 26 (2):147-54.

Das S. K., A. C. White and B. L. Fanburg, 1992. Modulation of Transforming Growth Factor- $\beta 1$ antiproliferative effects on endothelial cells by Cysteine, Cystine, and N-Acetylcysteine. J. Clin. Invest. Vol. 90, Nov., 1649-1656.

Dhouib I. E., M. Jallouli, A. Annabi, N. Gharbi, S. Elfazaa and M. M. Lasram, 2016. A minireview on N-acetylcysteine: An old drug with new approaches. Life Sci.ences 151:359-363.

Dos Santos G. C., L. M. G. Antunes, A. C. dos Santos, M. d. L. P. Bianchi. 2009. Coenzyme Q10 and its effects in the treatment of neurodegenerative diseases. Braz. J. Pharm. Sci: 45(4), p

Duncan, D.B., 1955. Multiple Range and Multiple F. Test Biometrics.,Biometrics. 11: 1-42.

El-Harairy M. A., Laila N. Eid, A. E. B. Zeidan, A.M. Abd El-Salaam and M. A. M. El-Kishk. 2011. Quality and fertility of the frozen-thawed bull semen as affected by the different cryoprotectants and glutathione levels. Journal of American Science, 7(5) p 791-801.

Fatimah S. I., F. H. F. Jaffar, K. Osman, S. F. S. Mohamed, C. F. Nang, N. H. Ismail, and M. I. Ismail, 2011. Bull spermatozoa motility: optimization of coenzyme q10 and alpha-lipoic acid concentration. IIOABJ; Vol. 2 (Issue 5:) pp. $8-13$.

Fischer J. and C.R. Ganellin, 2006. Analogue-Based Drug Discovery. Weinheim: Wiley-VCH. p. 544.

Gualtieri R., V. Barbato, I. Fiorentino, S. Braun, D. Rizos, S. Longobardi, R. Talevi, 2014. Treatment with zinc, D-aspartate, and coenzyme Q10 protects bull sperm against damage and improves their ability to support embryo development. Theriogenology, 82:592-598.

Howell B. F., S. McCune, R. Schaffer, 1979. Lactateto-pyruvate or pyruvate-to-lactate assay for lactate dehydrogenase: a re-examination. Clin. Chem., 25(2):269-72.

Hufana-Duran D., R. P. Mallari, D. P. Suba, P. G. Duran, E. A. Abella, and F.V. Mamuad, 2015. Hypo-Osmotic Swelling Test for Membrane Integrity Evaluation of Frozen-Thawed Water Buffalo (Bubalus bubalis Linn.) Spermatozoa. Philippine Journal of Science144 (2): 209-219.
Lenaz G. and M. L. Genova, 2009. Mobility and function of Coenzyme Q (ubiquinone) in the mitochondrial respiratory chain. Biochimica et Biophysica Acta - Bioenergetics, 1787(6) P: 563573

Matalliotakis I., Y. Koumantaki, A. Evageliou, G. Matalliotakis, A. Goumenou and E. Koumantakis, 2000. L-carnitine levels in the seminal plasma of fertile and infertile men: correlation with sperm quality. Int $\mathrm{J}$ Fertil Womens Med. May-Jun; 45(3):236-40.

Michael A., C. Alexopoulos, E. Pontiki, D. Hadjipavlou-Litina, P. Saratsis and C. Boscos, 2007. Effect of antioxidant supplementation on semen quality and reactive oxygen species of frozen-thawed canine spermatozoa. Theriogenology 68:204-212.

Miles M. V., 2007. The uptake and distribution of coenzyme Q (10)-10. Mitochondrion 7S: 72-77.

O'Flaherty C., 2014.The Enzymatic Antioxidant System of Human Spermatozoa. Advances in Andrology, Vol. 2014; p1-15.

Patel H. A., G. M. Siddiquee, D. V. Chaudhari and V. S. Suthar, 2016. Effect of different antioxidant additives in semen diluent on cryopreservability $\left(-196^{\circ} \mathrm{C}\right)$ of buffalo semen. Veterinary World, 9(3): 299-303.

Pinto E. M., L. González-Fernández, N. H. Rollán, C. T. Vega, V. Calle-Guisado, J. M. Gordún, F. M. S. Margallo, I. S. Á. Miguel, B. Macías-García, 2017. N-acetylcysteine does not improve sperm motility of Lidia Bull after prolonged epididymal storage. Journal of Veterinary Andrology, 2(1):23-29.

Rushworth G. F., and I. L. Megson, 2014. Existing and potential therapeutic uses for Nacetylcysteine: The need for conversion to intracellular glutathione for antioxidant benefits. Pharmacology \& Therapeutics 141:150-159

Saeed, A. M., H.A. El-Nagar Nagar, W.M. Wafa, and Y. S. Hussein, 2016. Effect of Coenzyme Q-10 as an antioxidant added to semen extender during cryopreservation of buffalo and cattle semen. J. Anim. and Poultry Prod., Mansoura Univ., Vol. 7 (11): $403-408$.

Salisbury G.W., N.L. Van- Demark, J.R. Lodge, 1978. Extenders and extension of unfrozen semen. In: Physiology of Reproduction and Artificial Insemination of Cattle. $2^{\text {nd }}$ ed., W. H. Freemen and Company, San Francisco, USA, pp.473-474.

Samuni Y., S. Goldstein, O. M. Dean and M. Berk, 2013. The chemistry and biological activities of $\mathrm{N}$-acetylcysteine. Biochimica et Biophysica Acta 1830:4117-29.

SAS (2009). SAS/STAT® ${ }^{\circledR} .2$ User's Guide, 2nd ed. Statistical Analysis System Institute, Inc., Gary. NC., USA.

Sato, M., A. Kurosawa, S. Ikeda, N. Watanabe, S. Odo, Y. Monji and S. Sukemori, 2008. Effect of L-carnitine supplementation to bulls on sperm motility maintenance under high environmental 
temperatures. Animal Behaviour and Management, 44 (4): 245:250.

Schmidt, E. and Schmidt, F. W. 1963. Enzym. Biol. Clin. 3: 1 .

Shoae, A. and Zamiri, M.J., 2008. Effect of butylated hydroxytoluene on bull sperm frozen in egg yolkcitrate extender. Anim. Reprod. Sci., 104: 414418.

Sikka, S.C., 2004. Role of oxidative stress and antioxidants in andrology and assisted reproductive technology. J. Androl. 25, 5-18.

Taha, T.A.; E.I. Abdel-Gawad and M.A. Ayoub. 2000. Monthly variations in some reproductive parameters of Barki and Awassi rams throughout 1 year under subtropical condition.2: Biochemical and enzymatic properties of seminal plasma. Anim. Sci., 71: 325.

Tariq M., M.S. Khan, M.G. Shah, A.R. Nisha, M. Umer, S.M. Hasan, A. Rahman and I. Rabbani, 2015. Exogenous antioxidants inclusion during semen cryopreservation of farm animals. Journal of Chemical and Pharmaceutical Research, 7(3):2273-2280.

Zhang X., Y. Zhou, W. Xia, H. Wu, K. Yao, H. Liu and C. Xiong, 2012. Effect of pre-freezing conditions on the progressive motility recovery rate of human frozen spermatozoa. Andrologia, $44,343-348$.

\section{كفاءة الحفظ بالتجميد للحيوانات المنوية لطلائق الفريزيان المحلية باستخدام مخفف التريس المعزز بمضادات الأكسدة الطبيعية او الصناعية الصفية بالبة}

قسم التكنولوجيا الحبيوية، معهل بحوث الإتتاج الحيوانس، مركز البحوث الزراعية، اللقي، الجبزة

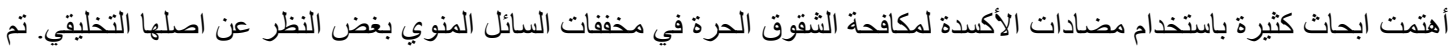

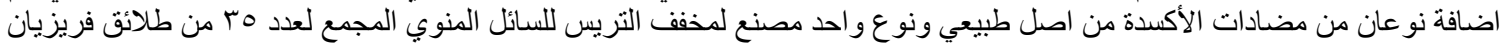

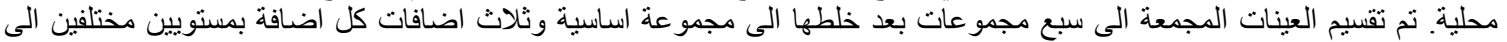

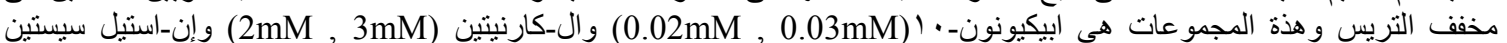

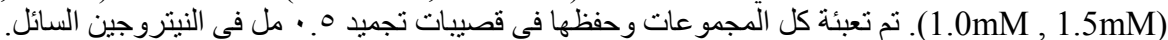

سجلت جميع القياسات الحيوية بعد التخفيف وبعد التجميد والإسالة وكذللك معدلات الأستعادة والنيات النشاط الأنزيمي لإنزيمات ALT,AST,LDH

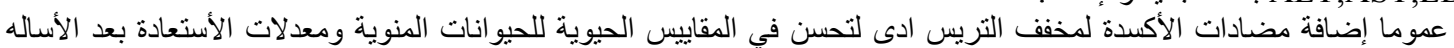

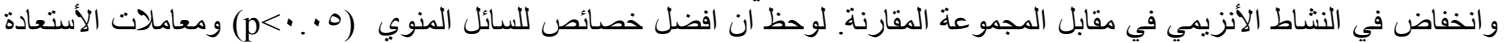

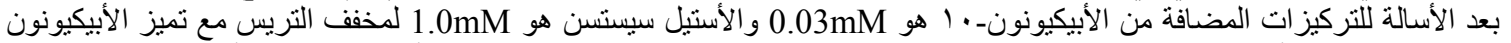

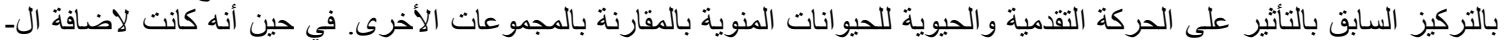

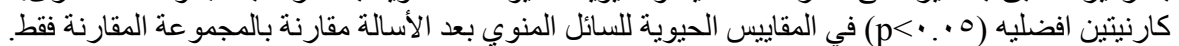

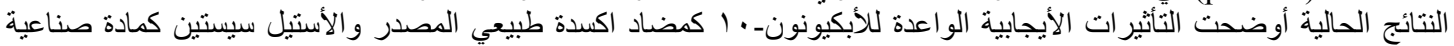
مخلقة على الحركة التقدية ولا سيما الحفاظ على التحام الأكروسوم بعد عمليتي التجميد و الأساله للحيوانات المنوية لطلائق الفريزيان 